\section{The Role of Youth Against Village Development through Karang Taruna Program in Karangpoh Village, Jatinom-Klaten}

\section{Peran Pemuda terhadap Pembangunan Desa melalui Program Karang Taruna di Desa Karangpoh, Jatinom-Klaten}

\author{
Prasetio Ariwibowo \\ Universitas Indraprasta PGRI Jakarta \\ Jalan Nangka Raya No. 58C, RT 05/05, Jakarta, Indonesia
}

\begin{abstract}
The purpose of this study was to determine youth participation in the Karang Taruna Desa program in terms of program management aspects and to find out the inhibiting and supporting factors of youth participation in the Karang Taruna village program. This research uses a qualitative approach with descriptive methods, data collection techniques carried out by interview, observation, and documentation. The validity of the data used is data triangulation, namely source triangulation. The data analysis technique is qualitative descriptive with the following stages: data collection, data reduction, presentation and conclusion drawing. The results obtained in this study (1) youth participation in the Karang Taruna village program viewed aspects of program management using four stages of participation, namely participation in planning; participation in implementation and participation in utilization; (2) factors that hamper youth participation in the Youth Organization program are limited time from individuals and lack of confidence to channel their potential. While the supporting factors are that individuals have high social awareness or spirit to build community through the Youth Organization program.
\end{abstract}

Keywords: youth organization, youth, development, Karangpoh Village, Klaten.

Abstrak

Tujuan penelitian ini adalah untuk mengetahui partisipasi pemuda dalam program Karang Taruna desa dilihat aspek pengelolaan program dan untuk mengetahui faktor penghambat dan pendukung partisipasi pemuda dalam program Karang Taruna desa. Penelitian ini menggunakan pendekatan kualitatif dengan metode deskriptif, teknik pengumpulan data dilakukan dengan cara wawancara, observasi, dan dokumentasi. Keabsahan data yang digunakan adalah triangulasi data yaitu triangulasi sumber. Teknik analisis data adalah deskriptif kualitatif dengan tahap sebagai berikut pengumpulan data, reduksi data, penyajian dan penarikan kesimpulan. Hasil yang diperoleh dalam penelitian ini (1) partisipasi pemuda dalam program Karang Taruna desa dilihat aspek pengelolaan program menggunakan empat tahap partisipasi, yaitu partisipasi dalam perencanaan; partisipasi dalam pelaksanaan dan partisipasi dalam pemanfaatan; (2) faktor yang menghambat partisipasi pemuda dalam program Karang Taruna yaitu keterbatasan waktu dari individu dan rasa kurang percaya diri untuk menyalurkan potensi yang dimiliki. Sedangkan faktor yang mendukung yaitu individu mempunyai kesadaran atau jiwa bersosial yang tinggi untuk membangun masyarakat melalui program Karang Taruna.

Kata Kunci : karang taruna, pemuda, pembangunan, Desa Karangpoh, Klaten
Literatus is a journal published by Neolectura, issued two times in one year. Literatus is a scientific publication media in the form of conceptual paper and field research related to social impact and cultural studies. It is hoped that Literatus can become a media for academics and researchers to publish their scientific work and become a reference source for the development of science and knowledge.

Our focus:

Social and Culture

Our Scope:

Humanities,

Education,

Management, History, Economics, Linguistics, Literature, Religion, Politics, Sociology, Anthropology, and others. 
Vol. 2, No. 1, April 2020, pp.59-65.

e-ISSN:

2686-5009

The Role of

Youth

Against

Village

Development

through

Karang

Taruna

Program in

Karangpoh

Village,

Jatinom-

Klaten

Prasetio

Ariwibowo

How to cite:

Ariwibowo, P. (2020).

The Role of Youth

Against Village

Development through Karang Taruna Program

in Karangpoh Village,

Jatinom-Klaten.

LITERATUS, 2 (1), 59-65.

https://doi.org/10.3701

0/lit.v2i1.35

\section{PRELIMINARY}

Karangpoh is a densely populated village consisting of hundreds of families.Karangpoh itself is a village that is strategically located, from the city center of Klaten, only $10 \mathrm{~km}$ away, while from Boyolali it is only $15 \mathrm{~km}$. This village also consists of two sub-districts, 2 sub-districts that enter are Jatinom and Karanganom sub-districts.Of the many residents who live here most of the livelihoods of businesses released from the days of ancestors to the present most of which work as craftsmen of agricultural equipment, while some are also farmers' professions.

Youth is a national asset which is very expensive and priceless. The progress or destruction of the nation and state depends a lot on the young people as agents of change. At every development and change of civilization there is always a young blood who pioneered it. However, young people in Indonesia today have lost much of their identity, especially in terms of nationalism and patriotism (love of Indonesia's homeland). Therefore we need a re-thinking (rethinking) and re-inventing (rediscovery) in the nation character building (development of national character) for youths who are nationalist and patriotism to rediscover national identity (Moerdiyanto, 2011: 2). The journey of a true nation cannot be separated from the existence of youth. In fact history has recorded, in the development of world civilization has proven the role of youth as the perpetrators of the birth of a new civilization. Likewise in the development of the birth of the Indonesian nation, both began in the struggle for independence, until after the nation's independence. This proves that youth are able to play an active role as the front guard in the process of struggle, renewal, and national development.

Youth are young people who must be seen as "personal" who are at a certain level in the development of a person's life, with certain qualities and characteristics, with certain rights and roles and obligations with certain potentials and needs (Chandra, 2011: 1 ). In the process of developing the country, youth is a moral force, social control, and an agent of renewal as an embodiment of its functions, roles, characteristics, and strategic position in national development. For this reason, the responsibilities and strategic role of youth in all dimensions of development need to be increased in accordance with the values contained in the Pancasila and the mandate of the Constitution of the Republic of Indonesia. Under Law No. 40 of 2009 that Youth organizations are formed by youth and function to support national interests, empowering potential, and developing leadership, entrepreneurship, pioneering. In this relationship young people have quite a lot of productive activity in their spare time. Among other young people who are studying or working outside the city there are no opportunities to participate in activities in his village, and vice versa young people who experience early marriage are preoccupied with taking care of their households rather than prioritizing youth activities.

Youth organizations in Indonesia aim to gather youth workers and channel them into productive activities. Abuse of this situation is certainly there, namely when the leaders of the youth association use its influence for their own interests and direct the group for purposes that are not good. But in 
normal circumstances, the existing youth association or organization, aside from being useful to contribute to the development of the country, also functions as the development of social attitudes of adolescents.

Karang Taruna is a Youth organization in Indonesia and is a place for the development of social life of the younger generation, Youth Organization grows on the awareness and sense of social responsibility of the community and for the community itself, especially the younger generation in a village, village or equivalent social community, especially engaged in the fields of social welfare (Wenti, 2013: 391). As in the fields of economics, sports, skills, religion and art in accordance with the purpose of the establishment of youth clubs to provide guidance and empowerment to young people in a village or region themselves, as a youth social organization the Youth Organization is a place or place for guidance and development in an effort to develop economic, social and cultural activities by utilizing all the potential that exists in the community both human and natural resources that are already available.

In a previous study conducted by Ismay Hilda entitled "The Role of Youth in Developing Young Generation in Bulusari Village, Bulakamba District, Brebes Regency" in 2011 stated that Youth Organization is a forum or vehicle for coaching young generation, to be able to grow and develop in accordance with the potential and ability. With this forum, it is hoped that the young generation will have a great sense of responsibility towards themselves, social and society. Thus the young generation can participate in development well.

In supporting activities in the community to achieve a goal is the desire of all people. For this reason, organizations were established to realize a desire to be achieved. Organizations are also needed to coordinate all available sources to get maximum results. The Karang Taruna Organization should get more attention from the community, the government and related parties. Because lately many young people are not getting enough attention and it's difficult to express themselves, so we can see what teenagers do now are things that are not expected by all parties.

The organization to be examined in this scientific work is an organization located in the environment and around the community, namely the Karang Taruna organization in the Karangpoh Village, Jatinom - Klaten. $40 \%$ of the Karangpoh Villagepopulation data obtained from the Jatinom - Klaten are youth. However, in reality there are still many young people who do not care or are not responsive to youth activities, for example youth who work or continue their education outside the area so that they are indifferent to Karang Taruna activities, youth who experience early marriage have more time to take care of the household they. The problems in this study are: 1) youth participation in the Karang Taruna village program seen in the aspect of program management, 2) inhibiting factors andsupport for youth participation in the village Youth Karang program.

Literatus is a journal published by Neolectura, issued two times in one year. Literatus is a scientific publication media in the form of conceptual paper and field research related to social impact and cultural studies. It is hoped that Literatus can become a media for academics and researchers to publish their scientific work and become a reference source for the development of science and knowledge.

Our focus: Social and Culture

Our Scope: Humanities, Education, Management, History, Economics, Linguistics, Literature, Religion, Politics, Sociology, Anthropology, and others. 
Vol. 2, No. 1, April 2020, pp.59-65.

e-ISSN:

2686-5009

The Role of

Youth

Against

Village

Development

through

Karang

Taruna

Program in

Karangpoh

Village,

Jatinom-

Klaten

Prasetio

Ariwibowo

How to cite:

Ariwibowo, P. (2020).

The Role of Youth

Against Village

Development through

Karang Taruna Program

in Karangpoh Village,

Jatinom-Klaten.

LITERATUS, 2 (1), 59-65.

https://doi.org/10.3701

0/lit.v2i1.35

\section{METHODE}

This research is a qualitative study so the approach used is a qualitative descriptive approach and will produce descriptive data in the form of written or oral words from people and observable behavior. The location of this study took place in Karangpoh Village, Jatinom - Klaten. The subject of this study was the chairman of Youth Organization and active youth as the main subject, besides the researchers also used supporting informants namely non-active youth and community leaders around the study site. The subjects of youth participation in the Karang Taruna Desa program consisted of 8 respondents. namely the Chairman of the Youth Organization and 1 community leader in Kupang Kidul. The focus in this research is youth participation in the village youth program seen aspects of program management and what factors are hampering and supporting youth participation in the village youth program. The main data sources in this study are words and actions, the rest are additional data such as documents and others. Data collection techniques namely, observation, interviews and documentation. Data analysis in this research is data reduction, data presentation, and drawing conclusions.

\section{RESULTS AND DISCUSSION}

Youth participation in the Karang Taruna village program in the Karangpoh Village, Jatinom-Klaten. is the involvement of youth and adolescents and is directly and indirectly responsible for the Karang Taruna program in the community group from the planning process, implementation until finally at the evaluation stage. There are three stages of participation in the Karangpoh Village program.

First, participation at the planning stage means the involvement of a person at the stage of preparing plans and strategies in preparing the committee for an activity / project. The community participates by giving suggestions, suggestions and criticisms through the meetings held.

Second, participation in implementation at this stage is meant is the involvement of someone at the stage of carrying out the work of an activity. Youth organization or youth here can provide energy and ideas as a form of participation in the activity.

And third, participation in the utilization at this stage is meant is the involvement of someone at the stage of utilizing an activity after the activity is completed. Community participation at this stage is in the form of personnel to operate and maintain the programs that have been built.

In dealing with youth and adolescents, of course, they will find an obstacle and support to know the participation of young generation, one of the obstacles is the lack of motivation and guidance from the government of the community itself and the support is the awareness of individual youth and adolescents to engage directly in youth activities. 
Youth participation in the Karang Taruna village program in Karangpoh Village, Jatinom - Klaten is an activity to generate feelings of being involved in organizational activities or the participation of individuals with self-awareness in an activity that is positive in order to develop common goals that build in the community. This is in accordance with the opinion of a scientist named Keith Davis stated his definition of participation cited by Sastropoetro (1988: 13) as follows, participation can be defined as mental or thought involvement or moral or feeling in group situations that encourage to contribute to the group in an effort to achieve goals and take responsibility for the business concerned. Based on this opinion, the participation is not based on physical involvement in the work but it involves a person's involvement so that it will cause a great responsibility and contribution to the group. In line with the opinion of Gordon W. Allport (in Sastropoetro, 1988: 12) statesthat, someone who participates actually experience the involvement of himself / his ego that is more than the involvement in work or tasks alone, with his involvement means the involvement of thoughts and feelings.

Some factors that hinder and support youth and youth in facing their participation in youth activities are the lack of motivation and guidance from the government of the community itself and what supports them is the awareness of individual youth and youth to engage directly in youth activities. This is in agreement with Munandar (2002: 316), "the inhibiting and supporting factors of creativity that come from individuals include the influence of habits and habits, lack of effort and mental laziness, determination in thinking, fear of taking risks, fearlessness to be different, tendency to follow other people's behavior patterns, feel determined by rice, a great sense of social life, willing to work together.

\section{CONCLUSION}

The conclusion from the results and discussion in this research is the participation of youth in the Karangpoh Village program in the Karangpoh Village, Jatinom - Klatenusing three stages of participation, namely participation in planning; participation in implementation; and participation in utilization. The inhibiting factor of youth participation in the Karang Taruna village program in Kupang Kidul hamlet is that many young people migrate both in terms of studies or in terms of work, lack of confidence to show their potential and many young people and adolescents who experience early marriage so that time preferably to take care of their household. The supporting factors of youth participation in the Karang Taruna village program in the Karangpoh Village, Jatinom - Klaten are individuals having high social awareness or soul so they care to develop and advance the community, especially youth and adolescents through the established youth program.

Suggestions delivered were youth and youth participation to be further improved in implementing the Youth Organization program by fostering a sense of responsibility to members of the Youth Organization, the head of Youth 


\section{Vol. 2, No. 1,} April 2020, pp.59-65.

e-ISSN:

2686-5009

Organization assigns tasks to members such as reporting on the results of the activity program so that it can be reported at each meeting, the Youth Organization administers innovation in the form of activities that attract the interests of youth and adolescents so that the goal of developing society is successful.

\section{BIBLIOGRAPHY}

The Role of Youth Against Village Development through

Karang

Taruna Program in Karangpoh Village, JatinomKlaten

Prasetio Ariwibowo

How to cite: Ariwibowo, P. (2020). The Role of Youth Against Village Development through Karang Taruna Program in Karangpoh Village, Jatinom-Klaten. LITERATUS, 2 (1), 59-65. https://doi.org/10.3701 0/lit.v2i1.35
Adi, I. R. (2001). Pemberdayaan, Pengambangan Masyarakat dan Intervensi Komunitas (Pengantar Pada Pemikiran dan Pendekatan Praktis). Jakarta: Lembaga Penerbit Fakultas Ekonomi Universitas Indonesia.

Afifuddin. (2009). Metodologi Penelitian Kualitatif. Bandung: Pustaka Setia.

Chandra, T. (2011). Pemberdayaan Pemuda Pengangguran Melalui Usaha Industri Kecil Kerajinan Sarung Tenun. (Studi pada Pengrajin Tenun di Kelurahan Wanarejan Utara Kabupaten Pemalang). Skripsi. (tidak diterbitkan).

Haditono, S. R. (2002). Psikologi Perkembangan. Yogyakarta: Gadjah Mada University Press.

Hilda, I. (2011). Peran Karang Taruna dalam Pembinaan Generasi Muda di Desa Bulusari Kecamatan Bulakamba Kabupaten Brebes. Tesis. (tidak diterbitkan).

Moerdiyanto. (2011). Pembangunan kepemimpinan pemuda berwawasan kebangsaan dan cinta tanah air. SELAPARANG. Jurnal Pengabdian Masyarakat Berkemajuan. Volume 2, Nomor 1. http://staff.uny.ac.id/sites/default/files/pengabdian/drs-moerdiyanto$\mathrm{mpd} /$ artikel-pengemb-kepemimpinan-pemuda-moer.pdf

Munandar. U. (2002). Kreativitas dan Keberbakatan: strategi mewujudkan potensi kreatif dan bakat. Jakarta: Gramedia Pustaka Utama

Rizqina, F. (2010). Partisipasi Masyarakat Dalam Implementasi Kebijakan Manajemen Berbasis Sekolah di Kecamatan Kalideres Kotamadya Jakarta Barat. http://www.lontar.ui.ac.id/file?file=digital/1302 95T+27161-Partisipasi+Masyarakat Literatur.pdf, diakses 6 Maret 2020.

Sastropoetro, S. R. A. (1988). Partisipasi, Komunikasi, Persuasi dan Disiplin dalam Pembangunan Nasional. Bandung: Alumni.

Slamet, Y. (1994). Pembangunan Masyarakat Berwawasan Partisipasi. Surakarta: UNS Press.

Sudibyo, L., dkk. (2013). Ilmu Sosial Budaya Dasar. Yogyakarta: Andi Offset 


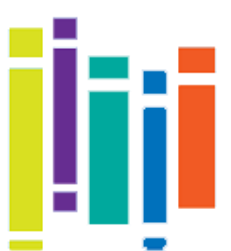

Sugiyono. (2012). Metode Penelitian Kuantitatif, Kualitatif, dan R\&D. Bandung: Alfabeta

Sugiyono. (2010). Memahami Penelitian Kualitatif. Bandung: Alfabeta

Suprijanto. (2007). Pendidikan Orang Dewasa dari Teori hingga Aplikasi. Jakarta: Bumi Aksara.

Suryana, S. (2010). Pemberdayaan Masyarakat. Jakarta: Bumi Aksara.

Purnomo, A. T. (2013). Partisipasi Masyarakat dalam Pemberdayaan melalui Program PNPM Mandiri Perkotaan di Kelurahan Sekaran Kecamatan Gunungpati Kota Semarang. Skripsi. Semarang. (tidak diterbitkan)

Walgito, B. (1999). Psikologi Sosial (Suatu Pengantar). Yogyakarta: Andi Offset

Wenti. (2013). Eksistensi Karang Taruna dalam Aktivitas Kepemudaan (Studi Kasus di Desa Gunawan Kecamatan Sesayap Kabupaten Tana Tidung). Ejournal Pemerintahan Integratif. http://ejournal.pin.or.id/site/?p=623.

Wibisono, C. (1989). Anatomi dan Profil Konglomerat Bisnis Indonesia. Jakarta: Management dan Usahawan Indonesia.

Kementerian Pemuda dan Olahraga Republik Indonesia. (2013). Peraturan Menpora RI No. 0059 Tahun 2013 tentang Pengembangan Kepemimpinan Pemuda. Jakarta.

Kementerian Sekretaris Negara Republik Indonesia. (2005). Undang-Undang RI No. 83 Tahun 2005 tentang Pedoman Dasar Karang Taruna. Jakarta.
Literatus is a journal published by Neolectura, issued two times in one year. Literatus is a scientific publication media in the form of conceptual paper and field research related to social impact and cultural studies. It is hoped that Literatus can become a media for academics and researchers to publish their scientific work and become a reference source for the development of science and knowledge.

\section{Our focus:}

Social and Culture

Our Scope:

Humanities,

Education,

Management,

History,

Economics,

Linguistics,

Literature,

Religion,

Politics,

Sociology,

Anthropology,

and others. 